\title{
Protein 3-nitrotyrosine formation during Trypanosoma cruzi infection in mice
}

M. Naviliat ${ }^{1,2}$,

G. Gualco ${ }^{3}$,

A. Cayota ${ }^{4}$ and R. Radi ${ }^{1}$

\author{
${ }^{1}$ Departamento de Bioquimica and Center for Free Radical and Biomedical Research, \\ ${ }^{2}$ Departamento de Reumatología, ${ }^{3}$ Departamento de Anatomía Patológica, \\ Hospital de Clínicas, ${ }^{4}$ Departamento de Medicina, Facultad de Medicina, \\ Universidad de la República, Montevideo, Uruguay
}

\footnotetext{
Correspondence

R. Radi

Departamento de Bioquímica

Facultad de Medicina

Universidad de la República

Avda. General Flores, 2125

Montevideo 11800

Uruguay

E-mail: rradi@fmed.edu.uy

Research supported by CSIC, Universidad de la República and the Howard Hughes Medical Institute.
}

Received January 4, 2005 Accepted August 30, 2005

\section{Abstract}

Nitric oxide $\left({ }^{\bullet} \mathrm{NO}\right)$ is a diffusible messenger implicated in Trypanosoma cruzi resistance. Excess production of $\bullet \mathrm{NO}$ and oxidants leads to the generation of nitrogen dioxide $\left(\bullet \mathrm{NO}_{2}\right)$, a strong nitrating agent. Tyrosine nitration is a post-translational modification resulting from the addition of a nitro $\left(-\mathrm{NO}_{2}\right)$ group to the ortho-position of tyrosine residues. Detection of protein 3-nitrotyrosine is regarded as a marker of nitro-oxidative stress and is observed in inflammatory processes. The formation and role of nitrating species in the control and myocardiopathy of $T$. cruzi infection remain to be studied. We investigated the levels of ${ }^{\bullet} \mathrm{NO}$ and protein 3-nitrotyrosine in the plasma of $\mathrm{C} 3 \mathrm{H}$ and $\mathrm{BALB} / \mathrm{c}$ mice and pharmacologically modulated their production during the acute phase of $T$. cruzi infection. We also looked for protein 3 -nitrotyrosine in the hearts of infected animals. Our results demonstrated that $\mathrm{C} 3 \mathrm{H}$ animals produced higher amounts of $\cdot \mathrm{NO}$ than $\mathrm{BALB} / \mathrm{c}$ mice, but their generation of peroxynitrite was not proportionally enhanced and they had higher parasitemias. While $\mathrm{N}_{\mathrm{G}}$-nitroarginine methyl ester treatment abolished ${ }^{\circ} \mathrm{NO}$ production and drastically augmented the parasitism, mercaptoethylguanidine and guanidoethyl disulfide, at doses that moderately reduced the ${ }^{\mathrm{NO}}$ and 3 nitrotyrosine levels, paradoxically diminished the parasitemia in both strains. Nitrated proteins were also demonstrated in myocardial cells of infected mice. These data suggest that the control of T. cruzi infection depends not only on the capacity to produce ${ }^{*} \mathrm{NO}$, but also on its metabolic fate, including the generation of nitrating species that may constitute an important element in parasite resistance and collateral myocardial damage.

\section{Introduction}

Chagas' disease is a parasitic condition caused by Trypanosoma cruzi that affects 16 to 18 million people in Central and South America and that can lead to impairment of heart function. During the acute phase of the

\section{Key words}

- Peroxynitrite

- Nitric oxide

- Nitrotyrosine

- Free radicals

- Trypanosoma cruzi

- Chagas' disease disease the parasite actively replicates principally in macrophages and myocardial cells and a high parasitemia is observed. However, in immunologically competent individuals, an inflammatory and immune response develops controlling the parasite replication. Macrophages play a central role in 
the anti-parasitic defense, mainly due to the production of nitric oxide $\left({ }^{\circ} \mathrm{NO}\right)(1)$.

- NO is a diffusible messenger produced by the reaction of L-arginine with different isoforms of nitric oxide synthases (NOS). ${ }^{\bullet} \mathrm{NO}$ has been implicated in different physiological functions, including vasodilation, inhibition of platelet aggregation, neurotransmission, and immune regulation (2), among others. In inflammatory conditions, large amounts of ${ }^{\circ} \mathrm{NO}$ can be produced after the induction of inducible NOS (iNOS) in different cell types, notably macrophages. During T. cruzi infection, - $\mathrm{NO}$ production, measured by its end products nitrite $\left(\mathrm{NO}_{2}^{-}\right)$plus nitrate $\left(\mathrm{NO}_{3}^{-}\right)\left(\mathrm{NO}_{\mathrm{x}}^{-}\right)$in serum or $\mathrm{NO}_{2}^{-}$in splenocyte culture supernatants, rises early after the infection and remains high throughout the acute phase $(3,4)$. Most of the current data indicate the necessity for ${ }^{\bullet} \mathrm{NO}$ to control the infection. The production of ${ }^{\bullet} \mathrm{NO}$ correlates with the resistance to $T$. cruzi infection in C57BL/6 mice (3), and the use of different iNOS inhibitors dramatically increases parasitemia and mortality (5). Indeed, interferon- $\gamma($ INF- $\gamma$ ) receptor or iNOS knock-out mice are extremely susceptible to T. cruzi infection (6-8). However, in contrast, a recent publication by Cummings and Tarleton (9) showed that iNOS knock-out mice are not more susceptible than wild type to $T$. cruzi infection.

Macrophage infection with $T$. cruzi may also induce the generation of reactive oxygen species (ROS) $(10,11)$, particularly superoxide $\left(\mathrm{O}_{2}{ }^{--}\right)$from the NADPH oxidasedependent respiratory burst (12). ROS have been implicated early in $T$. cruzi killing. The J774 macrophage cell clone $\mathrm{C} 3 \mathrm{C}$, unable to produce $\mathrm{O}_{2}{ }^{-}$and hydrogen peroxide $\left(\mathrm{H}_{2} \mathrm{O}_{2}\right)$, cannot control parasite growth when infected with T. cruzi (13).

Tyrosine nitration is a post-translational modification resulting from the addition of a nitro $\left(-\mathrm{NO}_{2}\right)$ group to the ortho-position of tyrosine residues. Two principal reaction pathways lead to 3-nitrotyrosine formation, both centered on the formation of nitrogen dioxide $\left({ }^{\circ} \mathrm{NO}_{2}\right)(14)$, a strong nitrating agent, namely, the peroxynitrite- and hemeperoxidase-dependent mechanisms. The formation of 3-nitrotyrosine is regarded as a marker of nitro-oxidative stress and is observed in inflammatory processes under excess production of ${ }^{-N O}$ and oxidants. 3-Nitrotyrosinecontaining proteins have been described in different human and animal diseases, particularly in various forms of myocarditis (for a review, see Ref. 15).

Peroxynitrite, myeloperoxidase and eosinophil peroxidase are cytotoxic for $T$. cruzi. Previous work from our laboratory has shown that macrophage-derived peroxynitrite is able to kill T. cruzi epimastigotes and to impair their replication and motility as well as their energetic, calcium and trypanothione metabolism $(16,17)$. In addition, peroxynitrite causes the nitration of $T$. cruzi proteins (18). Neutrophils are able to kill intracellular amastigotes by a mechanism mediated by myeloperoxidase and $\mathrm{H}_{2} \mathrm{O}_{2}$ (19). Also, eosinophil peroxidase-coated T. cruzi trypomastigotes became sensitized to macrophage destruction in the presence of $\mathrm{H}_{2} \mathrm{O}_{2}$ (20).

On the basis of this evidence, we hypothesize that nitrating molecules are formed during $T$. cruzi infection as part of the antiparasitic mechanisms, and also contribute to collateral host tissue damage. To test this hypothesis we estimated inflammatory cellderived $\bullet \mathrm{NO}$ and nitrotyrosine production in the plasma of two strains of mice with different susceptibility to $T$. cruzi infection (11) and pharmacologically modulated its production during the acute phase of the disease. We also searched for protein 3-nitrotyrosine in the hearts of infected animals.

\section{Material and Methods}

\section{Chemicals}

All chemicals were purchased from Sigma (St. Louis, MO, USA), excepted otherwise indicated. 


\section{Animals}

Eight- to 12-week-old BALB/c and C3H mice were obtained from the animal house of Instituto de Higiene (Facultad de Medicina, Universidad de la República, Montevideo, Uruguay) and breed and maintained as recommended (21).

\section{Parasites and experimental infections}

The Tulahuen-2 strain of T. cruzi was used in all studies. The animals were infected intraperitoneally with sublethal doses of blood-derived trypomastigote forms, i.e., 500 and 100 live parasites for BALB/c and $\mathrm{C} 3 \mathrm{H}$ mice, respectively. Parasitemia was measured in $8 \mu \mathrm{L}$ of blood obtained from the tail vein as described (22).

\section{Pharmacological intervention}

To modulate ${ }^{\circ} \mathrm{NO}$ production we used the NOS inhibitors $\mathrm{N}_{\mathrm{G}}$-nitro-L-arginine methyl ester (L-NAME) and guanido-ethyl disulfide (GED) as well as mercaptoethylguanidine (MEG), an iNOS inhibitor and peroxynitrite scavenger (23) that also reduces neutrophil infiltration (24). Mice received a daily intraperitoneal dose of $50 \mathrm{mg} / \mathrm{kg}$ L-NAME, $10 \mathrm{mg} / \mathrm{kg} \mathrm{MEG}$ or $7 \mathrm{mg} / \mathrm{kg}$ GED diluted in PBS or vehicle from the day of infection and throughout the experimental period. Similar L-NAME doses have been shown to inhibit ${ }^{\bullet} \mathrm{NO}$ production during $T$. cruzi infection in mice $(3,5)$. Also, $10 \mathrm{mg} / \mathrm{kg} \mathrm{MEG}$ inhibited $\mathrm{NO}$ formation and nitrotyrosine immunoreactivity in a rat model of lung inflammation (24). GED (7 mg/kg) represents the quantity that provides the same molar amount of guanidine residues as 10 $\mathrm{mg} / \mathrm{kg}$ MEG. Clinically healthy non-infected mice receiving L-NAME, MEG or GED were used as controls. MEG and GED were kindly provided by Dr. Csaba Szabó (Inoteck Pharmaceuticals Corporation, Beverly, MA, USA).

\section{Blood collection}

Blood was collected on day 17 postinfection (pi) from L-NAME-treated mice and on day 25 pi from MEG- and GEDtreated mice, when parasitemia started to decline. The hearts were removed, washed in PBS and fixed in $10 \%$ formalin (v/v) in PBS. Blood leaking from the heart was collected into heparinized tubes and centrifuged and then submitted to five cycles of freezing and thawing in order to eliminate parasites. Finally, plasma samples were maintained at $-20^{\circ} \mathrm{C}$ until use.

\section{Measurement of $\bullet \mathrm{NO}$}

The production of $\bullet \mathrm{NO}$ was estimated by measuring $\mathrm{NO}_{\mathrm{x}}{ }^{-}$in plasma by the Griess method (25) adapted to work with small volumes of sample. Briefly, $10 \mu \mathrm{L}$ of the sample or standard dilutions of $\mathrm{NO}_{3}{ }^{-}$were incubated on an ELISA plate (NUNC, Roskilde, Denmark) in the presence of 0.1 $\mathrm{U} / \mathrm{mL}$ Aspergillus sp nitrate reductase, $5 \mu \mathrm{M}$ flavin adenine dinucleotide (and $30 \mu \mathrm{M}$ NADPH for $15 \mathrm{~min}$ at $37^{\circ} \mathrm{C}$ in a final volume of $100 \mu \mathrm{L}$. Next, excess NADPH was oxidized with $100 \mathrm{U} / \mathrm{mL}$ lactate dehydrogenase and $0.3 \mathrm{mM}$ sodium pyruvate for $5 \mathrm{~min}$ at $37^{\circ} \mathrm{C}$ and then for $15 \mathrm{~min}$ at $4^{\circ} \mathrm{C}$, in a final volume of $200 \mu \mathrm{L}$. Diazotization was performed using $10 \mathrm{mM}$ sulfanilamide and 0.6 $\mathrm{M} \mathrm{HCl}$. In order to eliminate the precipitated proteins, the samples were centrifuged at $3000 \mathrm{~g}$ for $15 \mathrm{~min}$ at $4^{\circ} \mathrm{C}$. The supernatant was then transferred to a new ELISA plate, $10 \mathrm{mM} \mathrm{N}$-(1-naphthyl)-ethylenediamine was added, and absorbance was measured at 548 $\mathrm{nm}$ in a microplate reader (Labsystems Multiskan MS, Vantaa, Finland).

\section{Measurement of nitrated plasma proteins}

Nitrated plasma proteins were measured by ELISA (26). A standard solution of $1 \mathrm{mg} /$ $\mathrm{mL}$ bovine serum albumin (BSA) prepared 
in $100 \mathrm{mM}$ phosphate buffer, $\mathrm{pH}$ 7.4, was nitrated with $1 \mathrm{mM}$ peroxynitrite added as a single bolus. The nitrotyrosine content of the nitrated BSA was calculated spectrophotometrically as the difference of the absorbance at $\mathrm{pH} 6$ and 11 , at $420 \mathrm{~nm}\left(\varepsilon=4400 \mathrm{M}^{-1}\right.$ $\mathrm{cm}^{-1}$ ) (27). ELISA plates (NUNC) were coated with dilutions of nitrated BSA or plasma samples diluted $1 / 100$ in carbonate buffer (50 mM, pH 9) overnight at $4^{\circ} \mathrm{C}$ and then blocked with $1 \%$ gelatin diluted in PBS for $1 \mathrm{~h}$ at $37^{\circ} \mathrm{C}$. After washing, an antinitrotyrosine polyclonal antibody $(\mathrm{Ab})$ generated in our laboratory (28) diluted to 250 $\mathrm{ng} / \mathrm{mL}$ in PBS- $0.05 \%$ Tween 20 was incubated for $1 \mathrm{~h}$ at $37^{\circ} \mathrm{C}$ and detected using a goat anti-rabbit peroxidase-conjugated immunoglobulin polyclonal antibody (Amersham-Pharmacia, Arlington Height, IL, USA). The plates were then developed using $o$-phenylenediamine and absorbance was read at $452 \mathrm{~nm}$ using a microplate reader. The results are reported as pmol/mg plasma proteins.

\section{Immunohistochemistry}

Hearts were probed with anti-nitrotyrosine and anti-myeloperoxidase polyclonal Ab. After fixing, the specimens were cut into $5-\mu \mathrm{m}$ sections on silanized microscope slides. The anti-nitrotyrosine polyclonal $\mathrm{Ab}(5 \mathrm{ng} /$ $\mathrm{mL}$ ) was diluted in Tris-saline (50 mM Tris, $150 \mathrm{mM} \mathrm{NaCl}, \mathrm{pH}$ 7.4), incubated overnight, and then developed with a secondary

Figure 1. Parasitemia of Trypanosoma cruzi-infected BALB/c (A) and $\mathrm{C} 3 \mathrm{H} / \mathrm{c}$ mice $(\mathrm{B})$. Mice were infected with sublethal doses of Tulahuen-2 trypomastigotes and treated with mercaptoethylguanidine (filled squares), guanido-ethyl disulfide (circles) or $\mathrm{N}_{\mathrm{G}}$-nitro-L-arginine methyl ester (triangles), or not treated (open squares). Data are reported as means \pm SEM for 5 to 8 mice per group.

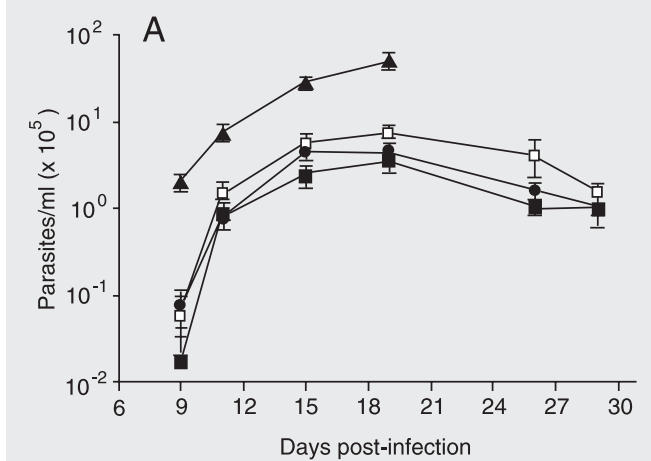

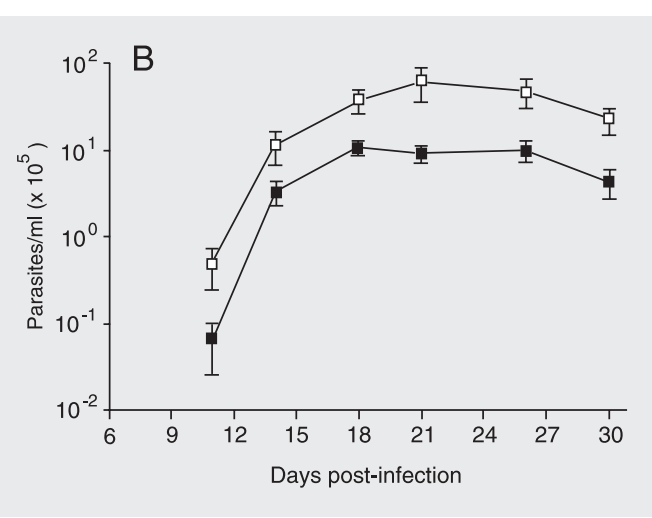

antibody coupled to biotin using a streptavidin-peroxidase kit and diaminobenzidine as chromogen. Histological sections were counterstained with hemalum. Diaminobenzidine tetrahydrochloride staining was enhanced by adding $0.03 \% \mathrm{NiCl}_{2}(\mathrm{w} / \mathrm{v})$ to the solution. Controls were performed with a pre-immune rabbit serum as the first antibody. The technical control was omission of the primary $\mathrm{Ab}$. The specificity of immunostaining was always assessed by competition with soluble $5 \mathrm{mM}$ 3-nitrotyrosine. For anti-myeloperoxidase staining we used a rabbit anti-human myeloperoxidase polyclonal Ab (RDI Research Diagnosis Inc., Flanders, NY, USA) diluted in Tris-saline containing goat serum, $1 / 8(\mathrm{v} / \mathrm{v})$. A preliminary study on mouse bone marrow performed in order to confirm the cross-reaction was positive.

\section{Statistical analysis}

Five to eight animals were included in each experimental group. All experiments were repeated three times. The results were compared by the Mann-Whitney-Wilcoxon test and a $P$ value $\leq 0.05$ was considered to be significant.

\section{Results}

\section{Parasitemia and mortality}

Previous studies have shown that, when infected with T. cruzi, BALB/c and $\mathrm{C} 3 \mathrm{H}$ 
mice display different degrees of macrophage activation as indicated by different amounts of ROS and TNF- $\alpha$ production $(11,29)$. Thus, since in the present study we evaluated the formation of ${ }^{\bullet} \mathrm{NO}$ and nitrotyrosine as a marker of nitro-oxidative stress during $T$. cruzi infection, we chose to work with the $\mathrm{C} 3 \mathrm{H}$ and $\mathrm{BALB} / \mathrm{c}$ strains. The animals were infected with a sublethal dose of parasites and treated with the NOS inhibitors L-NAME or GED or with MEG, the latter an iNOS inhibitor and peroxynitrite scavenger (23). L-NAME is a general NOS inhibitor which has already been used to inhibit ${ }^{\circ} \mathrm{NO}$ production during $T$. cruzi infection $(3,4,30)$. In turn, MEG and GED are guanidino compounds which are more specific for the inhibition of iNOS (31). In addition, due to its free thiol moiety, MEG reacts with peroxynitrite and its decomposition products, carbonate $\left(\mathrm{CO}_{3}{ }^{\circ}\right)$ and ${ }^{\circ} \mathrm{NO}_{2}$ radicals, and inhibits the nitration and oxidation reactions of peroxynitrite (23). MEG also displays different anti-inflammatory effects, including the inhibition of neutrophil migration and thus can inhibit the two main pathways of 3-nitrotyrosine formation (24, 32).

The parasitemias of control and LNAME-, MEG- or GED-treated BALB/c and $\mathrm{C} 3 \mathrm{H}$ mice are shown in Figure $1 \mathrm{~A}$ and $\mathrm{B}$, respectively. Untreated $\mathrm{C} 3 \mathrm{H}$ mice developed a parasitemia about one order of magnitude higher than untreated BALB/c animals. LNAME-treated BALB/c mice had a significantly higher parasitemia $(\mathrm{P}<0.05)$ throughout the infection than control animals. Unexpectedly, MEG-treated BALB/c and $\mathrm{C} 3 \mathrm{H}$ mice developed a significantly lower parasitemia $(\mathrm{P}<0.05$, from day 15 to 25 pi, i.e., 4 and 10-fold less for MEG than control at day 20 for $\mathrm{BALB} / \mathrm{c}$ and $\mathrm{C} 3 \mathrm{H}$, respectively) than non-treated animals. GED-treated BALB/c mice also showed a trend towards a decreased parasitemia which, however, was not statistically significant $(P=0.07)$. While L-NAME-treated BALB/c mice showed
$100 \%$ mortality at day 19 pi, all the MEGand GED-treated animals were alive at the end of the acute phase of the infection (Figure 2). Similarly, mortality of MEG-treated $\mathrm{C} 3 \mathrm{H}$ mice was null at 25 days pi (data not shown). A direct lethal effect of MEG and GED on the parasite was ruled out because none of these compounds at a concentration up to $3 \mathrm{mM}$ affected the growth of $T$. cruzi epimastigotes in culture (data not shown).

\section{Production of $\bullet$ NO}

-NO production during the immune response was evaluated by measuring the $\mathrm{NO}_{\mathrm{x}}{ }^{-}$ levels in plasma of control and infected, treated and untreated animals, at day 25 pi. T. cruzi infection led to an elevation of $\mathrm{NO}_{\mathrm{x}}{ }^{-}$ in both strains of mice (Table 1). However, the infected $\mathrm{C} 3 \mathrm{H}$ mice produced higher levels of $\mathrm{NO}$ (similar to published data, 33) than infected BALB/c animals. In turn, while L-NAME produced a profound inhibition of -NO synthesis, MEG and GED induced only a partial inhibition. Thus, there was no direct correlation between ${ }^{\circ} \mathrm{NO}$ levels (Table 1) and parasitemia (Figure 1), indicating that -NO is not the only molecule implicated in the control of the parasite growth, and that some ${ }^{\circ} \mathrm{NO}$-derived intermediate may participate in $T$. cruzi clearance.

\section{Detection of nitrated plasma proteins}

We measured the levels of nitrated plasma proteins in MEG- and GED-treated mice by

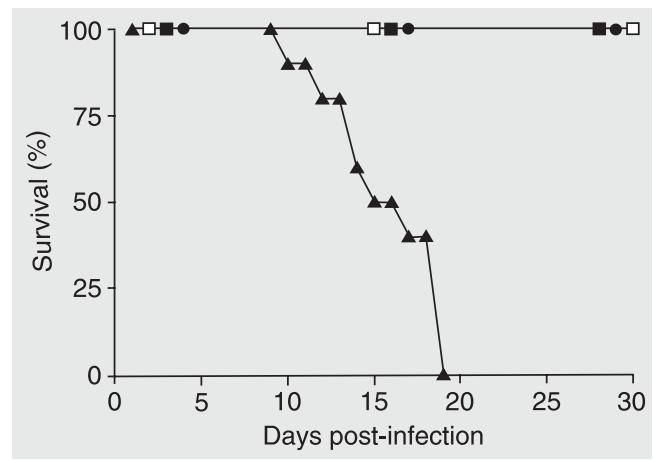

Figure 2. Mortality of BALB/C mice infected with sublethal doses of Tulahuen-2 trypomastigotes and treated with different iNOS inhibitors or a peroxynitrite scavenger or not treated (open squares). Mercaptoethylguanidine (filled squares), guanido-ethyl disulfide (circles), $\mathrm{N}_{\mathrm{G}}$-nitro-L-arginine methyl ester (triangles). Five to 8 mice were used in each group. 
ELISA as an index of the systemic formation of nitrating species. Table 2 shows that infected BALB/c mice had significantly higher levels of nitrated plasma proteins than uninfected mice ( $>7$-fold), while MEG or GED treatment of infected animals significantly decreased the amount of protein 3-nitrotyrosine in plasma. Uninfected $\mathrm{C} 3 \mathrm{H}$ mice had significantly higher basal levels of nitrated serum proteins than $B A L B / c$ mice and, when infected with $T$. cruzi, showed a moderate increase ( $\sim 1.6$-fold) in nitrated proteins compared to controls. Thus, in spite of the capac-

Table 1. $\mathrm{NO}_{\mathrm{x}}{ }^{-}$levels in plasma of Trypanosoma cruzi-infected and treated mice and controls.

\begin{tabular}{lcccc}
\hline & \multicolumn{4}{c}{$\mathrm{NO}^{-}(\mu \mathrm{M})$} \\
\cline { 2 - 5 } & PBS & GED & MEG & L-NAME \\
\hline BALB/c controls & $50.8 \pm 8.3$ & $60 \pm 12$ & $56.8 \pm 11.5$ & $47 \pm 6.3$ \\
BALB/c infected & $246.6 \pm 14.3^{\mathrm{a}, \mathrm{b}}$ & $166.8 \pm 28.4^{\mathrm{a}, \mathrm{c}}$ & $186.8 \pm 42.1^{\mathrm{a}, \mathrm{c}}$ & $90 \pm 8.7^{\mathrm{a}, \mathrm{c}}$ \\
C3H controls & $71.8 \pm 8$ & $\mathrm{ND}$ & $49 \pm 5^{\mathrm{c}}$ & $\mathrm{ND}$ \\
C3H infected & $434.7 \pm 63.4^{\mathrm{a}, \mathrm{b}}$ & $\mathrm{ND}$ & $251 \pm 41.2^{\mathrm{a}, \mathrm{c}}$ & ND \\
\hline
\end{tabular}

Data are reported in $\mu \mathrm{M}$ as means \pm SEM for 5 to 8 mice in each group. $\mathrm{NO}_{x}{ }^{-}$levels were measured as described in Material and Methods at day 25 post-infection. PBS = phosphate-buffered saline; GED = guanido-ethyl disulfide; $M E G=$ mercaptoethylguanidine; L-NAME $=\mathrm{N}_{\mathrm{G}}$-nitro-L-arginine methyl ester; ND = not determined. Significantly different values $(P<0.05)$ between: a) infected and non-infected mice of the same strain; b) non-treated BALB/c and $\mathrm{C} 3 \mathrm{H}$ mice; $c$ ) treated and non-treated animals of the same strain (Mann-Whitney-Wilcoxon test).

Table 2. Nitrotyrosine in plasma proteins of Trypanosoma cruzi-infected and treated mice and controls.

\begin{tabular}{lccc}
\hline & \multicolumn{3}{c}{ Nitrotyrosine in plasma proteins } \\
\cline { 2 - 4 } & PBS & GED & MEG \\
\hline BALB/c controls & $0.13 \pm 0.03$ & $0.16 \pm 0.03$ & $0.15 \pm 0.01$ \\
BALB/c infected & $18.4 \pm 5.96^{\mathrm{a}}$ & $14.78 \pm 1.46^{\mathrm{a}, \mathrm{c}}$ & $9.08 \pm 1.11^{\mathrm{a}, \mathrm{c}}$ \\
C3H controls & $1.28 \pm 0.47^{\mathrm{b}}$ & ND & $2.93 \pm 0.47$ \\
C3H infected & $3.18 \pm 1.02^{\mathrm{ab}}$ & ND & $4.38 \pm 0.86$ \\
\hline
\end{tabular}

Protein nitrotyrosine is reported in pmol/mg protein as means \pm SEM for 5 to 8 mice in each group. Nitrotyrosine levels were measured as described in Material and Methods at day 25 post-infection. PBS = phosphate-buffered saline; GED = guanido-ethyl disulfide; $\mathrm{MEG}=$ mercaptoethylguanidine; $\mathrm{L}-\mathrm{NAME}=\mathrm{N}_{\mathrm{G}}$-nitro-L-arginine methyl ester; ND = not determined. Significantly different values $(P<0.05)$ between: a) infected and non-infected mice; b) BALB/c and C3H mice; c) treated and non-treated animals of the same strain (Mann-Whitney-Wilcoxon test). ity of $\mathrm{C} 3 \mathrm{H}$ mice to produce much higher amounts of ${ }^{\bullet} \mathrm{NO}$ than $\mathrm{BALB} / \mathrm{c}$ mice (Table 1 ), in infected animals the levels of nitrated proteins were $\sim 2$-fold lower than those of $\mathrm{BALB} / \mathrm{c}$ animals. In BALB/c mice, a significant decrease of nitrated serum proteins was observed when the animals were treated with MEG.

\section{Protein 3-nitrotyrosine in chagasic myocardiopathy}

3-Nitrotyrosine in heart proteins was evaluated by immunohistochemistry. Protein 3-nitrotyrosine residues were not detected in hearts of infected animals until day 25 pi (data not shown). At this time, hemalum-eosin staining of the hearts indicated scarce inflammatory infiltrate and fibrosis. No polymorphonuclear cells were observed. Immunohistochemistry with a polyclonal anti-nitrotyrosine $\mathrm{Ab}$ showed diffuse myocardial immunoreactivity in infected animals (Figure 3D). The immunochemical labeling was stronger in the inflammatory areas. Intense labeling was observed in myocardial cells, with a membranous and granular cytoplasmic pattern (Figure 4). This study could not be performed in L-NAME-treated mice since all the animals died before protein 3-nitrotyrosine was detectable in the hearts. In MEG- and GED-treated mice, a trend towards less intense immunostaining was observed (data not shown), although the technique was not sensitive enough for quantitative purposes. In non-infected animals, no immunoreactivity against nitrotyrosine was observed (Figure 3A). Controls were performed to substantiate the specificity of the immunostaining, including specimens incubated with pre-immune serum (Figure 3B) and the co-incubation of the first $\mathrm{Ab}$ with $5 \mathrm{mM}$ nitrotyrosine, which completely blocked the reactivity (Figure 3C). Antimyeloperoxidase immunostaining showed no reactivity, consistent with the lack of neutrophil infiltration in this model. 


\section{Discussion}

Over the last few years, abundant evidence has been obtained for a role of ${ }^{\bullet} \mathrm{NO}$ in the host defense against $T$. cruzi infection as well as in other infectious and inflammatory diseases. It is now thought that many of the toxic effects of ${ }^{\bullet} \mathrm{NO}$ are due to its conversion to secondary ${ }^{\bullet} \mathrm{NO}$-derived oxidants including peroxynitrite (14).

In the present study, we investigated the production of 3-nitrotyrosine as an index of nitro-oxidative stress in order to determine if there is a link between 3-nitrotyrosine formation and host defense and/or pathology. Our results demonstrate that in $\mathrm{C} 3 \mathrm{H}$ animals, despite a higher ${ }^{\circ} \mathrm{NO}$ synthesis than in $\mathrm{BALB} / \mathrm{c}$ mice, the generation of 3-nitrotyrosine was not proportionally enhanced and the infection was poorly controlled. L-NAME treatment effectively reduced ${ }^{\mathrm{NO}}$ synthesis, inducing high parasitism and mortality. As expected, MEG- and GED-treated mice produced lower levels of ${ }^{\bullet} \mathrm{NO}$ and 3-nitrotyrosine than untreated animals, but surprisingly a lower extent of parasitism was observed. Thus, in untreated animals, the antiparasitic mechanisms seem to depend not only on the individual capacity to produce -NO, but also on the way its metabolism is directed, i.e., the ability to generate ${ }^{\circ} \mathrm{NO}$ derived oxidants constitutes an important element in parasite resistance. In agreement with this idea, the results of Cardoni et al. (11) demonstrated that, when infected with T. cruzi, BALB/c mice produced higher levels of ROS $\left(\mathrm{O}_{2}{ }^{\bullet-}, \mathrm{H}_{2} \mathrm{O}_{2}\right)$ than $\mathrm{C} 3 \mathrm{H}$ mice. These results could not be reproduced with MEG and GED treatments since the inhibition of $\mathrm{NO}$ and 3-nitrotyrosine formation occurred with a decreased parasitemia. In addition to its capacity to scavenge peroxynitrite, MEG has been shown to reduce IL$1 \beta$ and TNF- $\alpha$ and to prevent IK-B degradation (32). On the basis of these data, we reasoned that the results obtained with pharmacological intervention of NOS should be interpreted with caution since a drug (i.e., MEG) can modulate other processes in addition to the inflammatory response. There are no data on the effects of L-NAME and GED on the inflammatory response.

Except for the work of Cummings and Tarleton (9), the current consensus is that there is a need for ${ }^{-} \mathrm{NO}$ to control T. cruzi
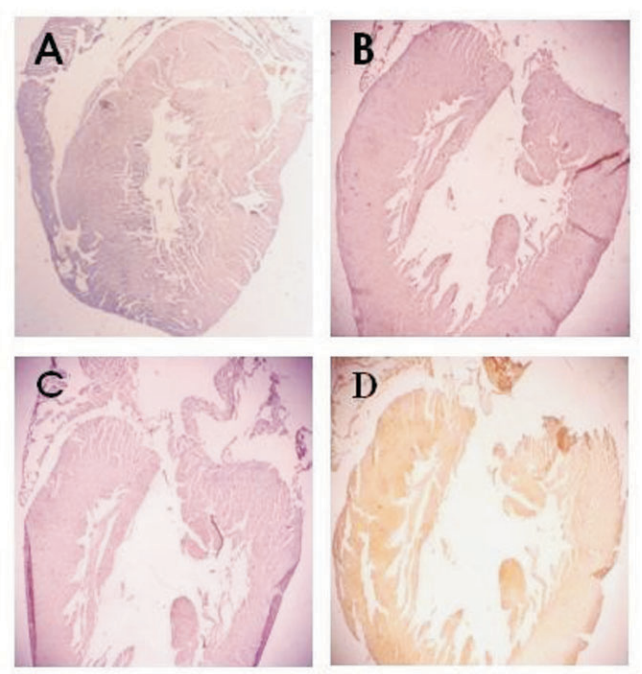

Figure 3. Immunohistochemical staining for protein nitrotyrosine residues in heart of $B A L B / c$ mice. The immunostaining was carried out as described in Material and Methods. $A$, Non-infected animal; $B, C$ and $D$, infected animals. $B$, Control with pre-immune serum; $C$, the antinitrotyrosine $A b$ binding was blocked with $5 \mathrm{mM}$ nitrotyrosine; $D$, slide incubated with anti-nitrotyrosine $\mathrm{Ab}$. A diffuse immunostaining (brown color) is observed in infected mice (D), but not in non-infected mice (A), neither in control $(B, C)$. Magnification $2 \mathrm{X}$.

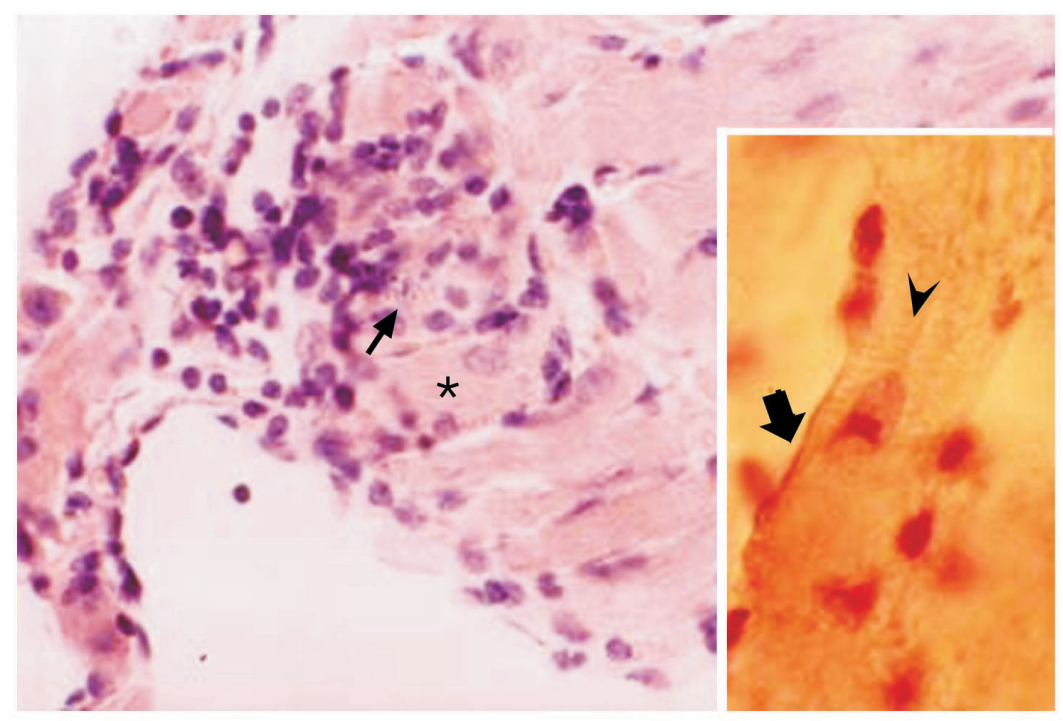

Figure 4. Immunohistochemical staining for protein nitrotyrosine residues in heart of an infected BALB/c mice. Diffuse immunostaining is observed in the myocardium (brown color), with stronger labeling in inflammatory areas, particularly around inflammatory cells (asterisk). Exceptionally, an amastigote nest was found in this slide (thin arrow), (magnification 10X). Hemalum stain nuclei in dark violet. Insert: $\mathrm{NiCl}_{2}$-intensified immunostaining. A strong immunostaining is observed in a myocardial cell membrane (thick arrow) and in the cytoplasm, where the immunostaining shows a clear granular pattern (arrowhead). Magnification, 40X. 
infection. It has been proved that mice treated with the ${ }^{-N O}$ inhibitors L-NAME (5) or NGmonomethyl-arginine (NMMA) $(3,4)$ and iNOS knock-out mice (6) are very susceptible to the infection. However, it is important to note that ${ }^{\circ O}$ induces immunosuppression by impairing $\mathrm{T}$ cell function. Early works have suggested its participation in the immunosuppression developed during infectious diseases characterized by strong macrophage activation, including $T$. brucei (34) and Salmonella typhimurium (35). During $T$. cruzi infection, it has been shown that the inhibition of the proliferative response of $\mathrm{T}$ lymphocytes of infected mice could be restored by the addition of L-NMMA (30). In addition, spleen cells from $T$. cruzi-infected INF- $\gamma$ knockout mice, that are unable to produce ${ }^{\bullet} \mathrm{NO}$, have a normal proliferative response (7). Thus, ${ }^{\circ} \mathrm{NO}$ cannot be regarded as a simple parasitized molecule since it displays multiple functions in the homeostasis of immune response.

We demonstrated anti-nitrotyrosine staining in hearts of infected mice. While the diffuse immunostaining suggests the formation of nitrotyrosine by myocardial cells, the concomitant induction of iNOS (36) and the presence of a stronger labeling in inflammatory areas indicate that these cells also participate in the generation of nitrating agents. A partial inhibition of iNOS and the scavenging of peroxynitrite resulted in a lower formation of 3-nitrotyrosine in chagasic myocardium. There is abundant evidence that peroxynitrite participates in different cardiac diseases, including autoimmune myocarditis, heart failure and cardiac allograft rejection (15) secondary to the nitration and inhibition of myofibrillar creatine kinase and the reduction of cell contractility. Thus, it can be postulated that peroxynitrite can mediate myocardial dysfunction during Chagas' disease. Another interesting point to investigate in chagasic myocardiopathy is the role of peroxynitrite in the loss of peripheral autonomic neurons. It has been demon- strated that $T$. cruzi-infected rats treated with NMMA have a decreased loss of peripheral autonomic neurons in heart and colon than untreated animals in spite of an increased parasitism in these tissues (37). A question that rises from these results is whether the neuronal damage is due directly to the inhibition of ${ }^{\bullet} \mathrm{NO}$ or to peroxynitrite production.

The nitrating species in our experimental model cannot be identified with certainty. However, we can speculate that peroxynitrite is responsible for most of the nitration observed. The anti-parasite response is developed mainly in lymphoid organs where the synthesis of peroxynitrite has been described (8) and in the myocardium where the anti-nitrotyrosine staining co-localizes with anti-iNOS labeling (36). In the present study, the reduced participation of polynuclear cells in the inflammatory infiltrate of the myocardium, even during the early stages of the infection, and the negativity of the immunostaining against myeloperoxidase (data not shown) allow us to suggest the idea that, in our experimental model, peroxynitrite is the main nitrating species.

The precise role of these nitrogen and ROS during $T$. cruzi infection in vivo remains to be elucidated. In the particular case of peroxynitrite we can speculate, in the light of published data, that it could have a direct toxic effect on the parasite and a role in the regulation of the immune response. Work from our group has demonstrated that peroxynitrite impairs the antioxidant defenses (18) as well as the energy and calcium metabolism of cultured epimastigotes and reduces their motility and replication rates (38). In agreement with this idea, Linares et al. (39) showed that peroxynitrite is the molecule responsible for the resistance of C57BL/ 6 mice to L. amazonensis infection. In addition, by affecting tyrosine phosphorylation pathways, peroxynitrite is able to modulate the activation and proliferation of T lymphocytes (28).

In the light of current data, we consider 
that the precise role of ${ }^{\bullet} \mathrm{NO}$ during $T$. cruzi infection needs to be reconsidered. In general, these data suggest that while ${ }^{\circ} \mathrm{NO}$ is necessary for parasite clearance, when efficiently synergizing with other ROS (14), high ${ }^{\circ} \mathrm{NO}$ levels can inhibit the anti-parasite response and produce tissue injury through the formation of peroxynitrite or other nitrating molecule. An efficient control of the infection requires ${ }^{*} \mathrm{NO}$ levels high enough for a lytic effect, probably due to the generation of peroxynitrite or other nitrating mole- cule, but insufficient to promote the suppression of the immune response and tissue injury. Further work is necessary to understand the respective role of $\bullet \mathrm{NO}$ and peroxynitrite in the pathophysiology of Chagas' disease ${ }^{1}$.

\section{Acknowledgments}

We thank Dr. Otto Pritsch for a critical reading of the manuscript.

${ }^{1}$ Moreover, the genetically modified NADPH oxidase knock-out mice (40) can help to define the role of macrophage-derived superoxide in infection control for which no good pharmacological strategies exist.

\section{References}

1. Silva JS, Machado FS \& Martins GA (2003). The role of nitric oxide in the pathogenesis of Chagas' disease. Frontiers in Bioscience, 8: 314-325.

2. Mariotto S, Menegazzi M \& Suzuki H (2004). Biochemical aspects of nitric oxide. Current Pharmaceutical Design, 10: 1627-1645.

3. Vespa GNR, Cunha FQ \& Silva JS (1994). Nitric oxide is involved in control of Trypanosoma cruzi-induced parasitemia and directly kills the parasite in vitro. Infection and Immunity, 62: 5177-5182.

4. Petray P, Rottenberg ME, Grinstein S et al. (1994). Release of nitric oxide during the experimental infection with Trypanosoma cruzi. Parasite Immunology, 16: 193-199.

5. Petray P, Castanos-Velez E, Grinstein S et al. (1995). Role of nitric oxide in resistance and histopathology during experimental infection with Trypanosoma cruzi. Immunology Letters, 47: 121-126.

6. Hölscher C, Köhler G, Müller U et al. (1998). Defective nitric oxide effector functions lead to extreme susceptibility of Trypanosoma cruzi-infected mice deficient in gamma interferon receptor or inducible nitric oxide synthase. Infection and Immunity, 66: 1208-1215.

7. Martins GA, Vieira LQ, Cunha FQ et al. (1999). Gamma interferon modulates CD95 (Fas) and CD95 ligand (Fas-L) expression and nitric oxide-induced apoptosis during the acute phase of Trypanosoma cruzi infection: a possible role in immune response control. Infection and Immunity, 67: 3864-3871.

8. Rottemberg ME, Castanos-Velez E, de Mesquita R et al. (1996). Intracellular co-localization of Trypanosoma cruzi and inducible nitric oxide synthase (iNOS): evidence for dual pathway of iNOS induction. European Journal of Immunology, 26: 3203-3213.

9. Cummings $K L$ \& Tarleton RL (2004). Inducible nitric oxide synthase is not essential for control of Trypanosoma cruzi infection in mice. Infection and Immunity, 72: 4081-4089.

10. Cardoni R, Rottemberg M \& Segura E (1990). Increased production of reactive oxygen species by cells from mice acutely infected with Trypanosoma cruzi. Cellular Immunology, 128: 11-21.
11. Cardoni R, Antunez MI, Morales C et al. (1997). Release of reactive oxygen species by phagocytic cells in response to live parasites in mice infected with Trypanosoma cruzi. American Journal of Tropical Medicine and Hygiene, 56: 329-334.

12. Docampo R, Casellas AM, Madeira ED et al. (1983). Oxygen-derived radicals from Trypanosoma cruzi-stimulated human neutrophils. FEBS Letters, 155: 25-30.

13. Tanaka Y, Tanowitz H \& Bloom BR (1983). Growth of Trypanosoma cruzi in a cloned macrophage cell line and in a variant defective in oxygen metabolism. Infection and Immunity, 41: 1322-1331.

14. Radi R (2004). Nitric oxide, oxidants, and protein tyrosine nitration. Proceedings of the National Academy of Sciences, USA, 101: 40034008.

15. Turko IV \& Murad F (2002). Protein nitration in cardiovascular diseases. Pharmacological Reviews, 54: 619-634.

16. Rubbo H, Radi R, Trujillo M et al. (1994). Nitric oxide regulation of superoxide and peroxynitrite-dependent lipid peroxidation. Formation of novel nitrogen-containing oxidized lipid derivatives. Journal of Biological Chemistry, 269: 26066-26075.

17. Alvarez MN, Piacenza L, Irigoin F et al. (2004). Macrophage-derived peroxynitrite diffusion and toxicity to Trypanosoma cruzi. Archives of Biochemistry and Biophysics, 432: 222-232.

18. Thomson L, Denicola A \& Radi R (2003). The trypanothione-thiol system in Trypanosoma cruzi as a key antioxidant mechanism against peroxynitrite-mediated cytotoxicity. Archives of Biochemistry and Biophysics, 412: 55-64.

19. Villalta F \& Kierszenbaum F (1983). Role of polymorphonuclear cells in Chagas' disease. I. Uptake and mechanism of destruction of intracellular (amastigote) forms of Trypanosoma cruzi by human neutrophils. Journal of Immunology, 131: 1504-1510.

20. Nogueira NM, Klebanoff SJ \& Cohn ZA (1982). T. cruzi: sensitization to macrophage killing by eosinophil peroxidase. Journal of Immunology, 128: 1705-1708. 
21. Consejo DCdIUdIR (2000). Ordenanza sobre uso de animales de experimentación, docencia e investigación universitaria. Diario Oficial, Montevideo, Paraguay, 64-68.

22. Brener $Z$ (1962). Therapeutic activity and criterion of cure in mice experimentally infected with Trypanosoma cruzi. Revista do Instituto de Medicina Tropical de São Paulo, 4: 396-398.

23. Szabo C, Ferrer-Sueta G, Zingarelli B et al. (1997). Mercaptoethylguanidine and guanidine inhibitors of nitric-oxide synthase react with peroxynitrite and protect against peroxynitrite-induced oxidative damage. Journal of Biological Chemistry, 272: 9030-9036.

24. Cuzzocrea S, Zingarelli B, Hake P et al. (1998). Antiinflammatory effects of mercaptoethylguanidine, a combined inhibitor of nitric oxide synthase and peroxynitrite scavenger, in carrageenan-induced models of inflammation. Free Radical Biology and Medicine, 24: 450-459.

25. Schmidt HHHW \& Kelm M (1996). Determination of nitrite and nitrate by the Griess reaction. In: Feelisch M \& StamLer JS (Editors), Methods in Nitric Oxide Research. John Wiley \& Sons Ltd., New York.

26. Radi R, Peluffo G, Alvarez MN et al. (2001). Unraveling peroxynitrite formation in biological systems. Free Radical Biology and Medicine, 30: 463-488.

27. Crow JP \& Ischiropoulos H (1996). Detection and quantitation of nitrotyrosine residues in proteins: in vivo marker of peroxynitrite. Methods in Enzymology, 269: 185-194.

28. Brito C, Naviliat M, Tiscornia AC et al. (1999). Peroxynitrite inhibits T lymphocyte activation and proliferation by promoting impairment of tyrosine phosphorylation and peroxynitrite-driven apoptotic death. Journal of Immunology, 162: 3356-3366.

29. Russo M, Starobinas N, Ribeiro-Dos-Santos R et al. (1989). Susceptible mice present higher macrophage activation than resistant mice during infections with myotropic strains of Trypanosoma cruzi. Parasite Immunology, 11: 385-395.

30. Abrahamsohn IA \& Coffman RL (1995). Cytokine and nitric oxide regulation of the immunosuppression in Trypanosoma cruzi infection. Journal of Immunology, 155: 3955-3963.
31. Hasan K, Heesen BJ, Corbett JA et al. (1993). Inhibition of nitric oxide by guanidines. European Journal of Pharmacology, 249: 101106.

32. Lancel S, Tissier S, Mordon S et al. (2004). Peroxynitrite decomposition catalysts prevent myocardial dysfunction and inflammation in endotoxemic rats. Journal of the American College of Cardiology, 43: 2348-2358.

33. Shedlofsky SI, Tosheva RT \& Snawdwe JA (2000). Depression of constitutive murine cytochromes $\mathrm{P} 450$ by staphylococcal enterotoxin B. Biochemical Pharmacology, 59: 1295-1303.

34. Stenberg J \& McGuigan F (1992). Nitric oxide mediates suppression of T cell responses in murine Trypanosoma brucei infection. European Journal of Immunology, 22: 2741-2744.

35. Eisenstein TK, Huang D, Meissler JJ et al. (1994). Macrophage nitric oxide mediates immuno-suppression in infectious inflammation. Immunobiology, 191: 493-502.

36. Chandrasekar B, Melby PC, Troyer DA et al. (2000). Differential regulation of nitric oxide synthase isoforms in experimental acute chagasic cardiomyopathy. Clinical and Experimental Immunology, 121: $112-119$.

37. Garcia SB, Paula JS, Giovannetti GS et al. (1999). Nitric oxide is involved in the lesions of the peripheral autonomic neurons observed in the acute phase of experimental Trypanosoma cruzi infection. Experimental Parasitology, 93: 191-197.

38. Rubbo H, Denicola A \& Radi R (1994). Peroxynitrite inactivates thiol-containing enzymes of Trypanosoma cruzi energetic metabolism and inhibits cell respiration. Archives of Biochemistry and Biophysics, 308: 96-102.

39. Linares E, Giorgio S, Mortara RA et al. (2001). Role of peroxynitrite in macrophage microbicidal mechanisms in vivo revealed by protein nitration and hydroxylation. Free Radical Biology and Medicine, 30: 1234-1242.

40. Shiloh MU, MacMicking JD, Nicholson S et al. (1999). Phenotype of mice and macrophages deficient in both phagocyte oxidase and inducible nitric oxide synthase. Immunity, 10: 29-38. 